Article

\title{
Comparison of the Vegetation Effect on ET Partitioning Based on Eddy Covariance Method at Five Different Sites of Northern China
}

\author{
Hongchang $\mathrm{Hu}^{1}{ }^{\text {, Lajiao Chen }}{ }^{2,3, *}$, Hui Liu ${ }^{4}$, Mohd Yawar Ali Khan ${ }^{1}$, Qiang Tie ${ }^{1}$, \\ Xuejun Zhang ${ }^{4}$ and Fuqiang Tian ${ }^{1}$ \\ 1 Department of Hydraulic Engineering, State Key Laboratory of Hydroscience and Engineering, \\ Tsinghua University, Beijing 100084, China; huhongchang@tsinghua.edu.cn (H.H.); \\ yawar@tsinghua.edu.cn (M.Y.A.K.); tieqiang@tsinghua.edu.cn (Q.T.); tianfq@tsinghua.edu.cn (F.T) \\ 2 Institute of Remote Sensing and Digital Earth, Chinese Academy of Sciences, Beijing 100094, China \\ 3 Department of Geography and Geographic Information Science, University of Illinois at Urbana-Champaign, \\ Urbana, IL 61801, USA \\ 4 China Institute of Water Resources and Hydropower Research, Beijing 100038, China; \\ wuyouliuhui@163.com (H.L.); zhangxj@iwhr.com (X.Z.) \\ * Correspondence: chenlj@radi.ac.cn
}

Received: 9 October 2018; Accepted: 1 November 2018; Published: 7 November 2018

check for updates

\begin{abstract}
Vegetation exerts profound influences on evapotranspiration (ET) partitioning. Many studies have demonstrated the positive impact of vegetation cover on the ratio of transpiration (T) to ET. Whether it is universally true with regard to different vegetation types and different sites is understudied. In this study, five sites in Northern China with different vegetation types were selected for comparison study. ET partitioning is conducted using an approach based on the concept of the underlying water use efficiency with eddy covariance measurements. The results show various patterns of vegetation's effects over ET partitioning and, when compared with existing studies, also reveal a new relationship between the T/ET ratio and Normalized Difference Vegetation Index (NDVI) at some of the sites. At the alpine meadow site, the T/ET ratio gradually increase when NDVI is low and rapidly increase as NDVI go beyond a certain value, whereas at the arid shrub site, the T/ET ratio rapidly increase when NDVI is low and plateaus at a certain value when NDVI reaches a relatively high value. In deciduous forest, the T/ET ratio becomes unresponsive to NDVI beyond a threshold value. This study also reveals that irrigation schemes play a major role in determining the correlation between the T/ET ratio and NDVI because the T/ET ratio becomes well correlated with NDVI in case of flood irrigation and irrelevant to NDVI in the case of mulch drip irrigation. Furthermore, this study helps us to understand ET partitioning under different sites and different human activities such as irrigation. These findings can help policymakers to better understand the connection between vegetation and climate change or human activities and provide significant information for water management policy.
\end{abstract}

Keywords: ET partitioning; vegetation; eddy covariance; underlying water use efficiency $(u W U E)$; NDVI; climate change

\section{Introduction}

ET, a key process for connecting water, carbon, and energy across various ecosystems [1], consists of evaporation (E) and T from wet surfaces and vegetation through the stomata. Partitioning of ET into biological component $\mathrm{T}$ and non-biological component $\mathrm{E}$ is of great significance in order to improve our understanding of abiotic and biotic ecosystem processes, such as vegetation water use efficiency, interaction of water, and carbon cycles [2-6]. Terrestrial vegetation has significant impacts on ET 
partitioning owing to the fact that transpiration accounts for the major portion of ET and is intrinsically linked to photosynthesis or plant productivity $[7,8]$. Furthermore, how vegetation responds to climate change is complex, particularly under climate extremes such as drought, which makes the relationship between vegetation and ET partitioning more complicated $[9,10]$.

Previously, many efforts have been devoted to investigating the relationship between vegetation and ET partitioning on different spatial and temporal scales [11-14]. It has been reported that the T/ET ratio fluctuates among different vegetation types [15] and normally increases from grass to shrub to trees. For instance, Moran et al. [16] estimated the T/ET ratio in a grassland and shrub site within the Walnut Gulch Experimental Watershed in southeast Arizona, USA. The outcomes showed that T/ET is higher for the grass-dominated site compared to the shrub-dominated site. Furthermore, some studies also revealed that the T/ET ratio is higher for deep-rooted trees as compared to grasses. Apart from vegetation type, ET partitioning is also significantly associated with vegetation index. The majority of studies in the past stated that T/ET ratio is positively correlated to leaf area index (LAI). For instance, Raz-Yaseef et al. [17] found that the expansion of LAI leads to the increase of transpiration and the decrease of soil evaporation. The isotopic analysis by Wang et al. [12] revealed increments from 0.6 to 0.83 in the T/ET as the vegetation cover increases from $25 \%$ to $83 \%$. Zhou et al. [18] found a linear relationship between T/ET and enhanced vegetation index (EVI). Several studies also found that the influence of LAI on ET partitioning is distinctive with different levels of LAI. Liu et al. [19] illustrated that the increase of LAI led to an increase in the T/ET ratio; however, when LAI is over a specific range, the T/ET ratio is insensitive to the change in LAI. In a word, although it is reported that the $\mathrm{T} / \mathrm{ET}$ ratio and vegetation have a positive correlation in the existing studies, whether it is universally true with regard to different vegetation types and different sites is understudied.

ET partitioning can be commonly achieved by combining different in situ measurements [20], such as EC measurements [21-24], Bowen ratio [25,26], sap flow [27,28], plant weighing lysimeters [29-31], soil chamber measurements [32,33], $\mathrm{CO}_{2}$ and isotopic labeling [34-38], however, there is still huge uncertainty in ET partitioning due to the uncertainty of stomata behavior and a lack of high-density observation [39]. Recently, EC measurement has demonstrated its potential for ET partitioning [40-42]. The EC-based approach has several advantages that make it suitable for ET partitioning. First, due to its high frequency, it is capable of capturing small eddies, contributing to the turbulent transfer [43]. Secondly, it measures continuously and could provide long-term measurements, which is valuable for ET partitioning on multiple time scales.

Therefore, the present study aims to examine the relationship between vegetation and T/ET ratio among different sites and vegetation types. For this, five different sites situated in Northern China are selected for the comparison of ET partitioning. ET partitioning is conducted using an approach based on the concept of the underlying water use efficiency with eddy covariance measurements. MODIS-determined NDVI is utilized to represent vegetation dynamics to investigate the relationship of vegetation and ET partitioning. The outcome of this study is also significant as ET partitioning is a crucial process for understanding how vegetation responds to environmental change.

\section{Materials and Methods}

\subsection{Description of the Study Area}

This study is conducted at five sites in Northern China with different vegetation types, viz., typical arid, semi-arid, and semi-humid ecosystems, and located around $40^{\circ} \mathrm{N}$ with annual precipitation ranging from 62.0 to $541.0 \mathrm{~mm}$ and annual mean temperature varying between -5.0 and $12.5{ }^{\circ} \mathrm{C}$. Alpine meadow, arid shrub, deciduous forest, and crops are the four vegetation types chosen for the present study (Table 1). 
Table 1. Information on the five sites.

\begin{tabular}{cccccccc}
\hline Sites & Vegetation & Latitude & Longitude & $\begin{array}{c}\text { Elevation } \\
(\mathbf{m})\end{array}$ & $\begin{array}{c}\text { Annual } \\
\text { Precipitation } \\
(\mathbf{m m})\end{array}$ & $\begin{array}{c}\text { Annual } \\
\text { Temperature } \\
\left({ }^{\circ} \mathbf{C}\right)\end{array}$ & $\begin{array}{c}\text { Period of } \\
\text { Records }\end{array}$ \\
\hline Arou & Meadow & 38.0 & 100.5 & 3033 & 445.0 & -5.0 & $2013-2015$ \\
Daman & Spring wheat and maize & 38.9 & 100.4 & 1516 & 204.0 & 5.4 & $2013-2015$ \\
Sidaoqiao & Shrub & 42.0 & 101.1 & 873 & 116.8 & 9.6 & $2013-2015$ \\
Xinier & Crop & 41.6 & 86.2 & 886 & 62.0 & 12.5 & $2013-2016$ \\
Xitaizi & Forest & 40.5 & 116.6 & 974 & 541.0 & 7.5 & $2015-2016$ \\
\hline
\end{tabular}

Arou is located in a river valley highland on the south of Babao River, upstream of Heihe River (Figure 1) [44]. The climate of this site is a typical highland continental climate characterized by temperature variation. The average annual temperature, precipitation, and evapotranspiration are $-5.0^{\circ} \mathrm{C}, 445.0 \mathrm{~mm}$, and $1300.0 \mathrm{~mm}$, respectively. The site mainly consists of grassland, comprising alpine and mountain meadow. The height of the meadow varies during the year, with $20-30 \mathrm{~cm}$ in summer and several centimeters in other periods. The surface and the deeper soil are composed of clay and sandy clay loam, respectively; however, permafrost and seasonally frozen soil also exist in this area.

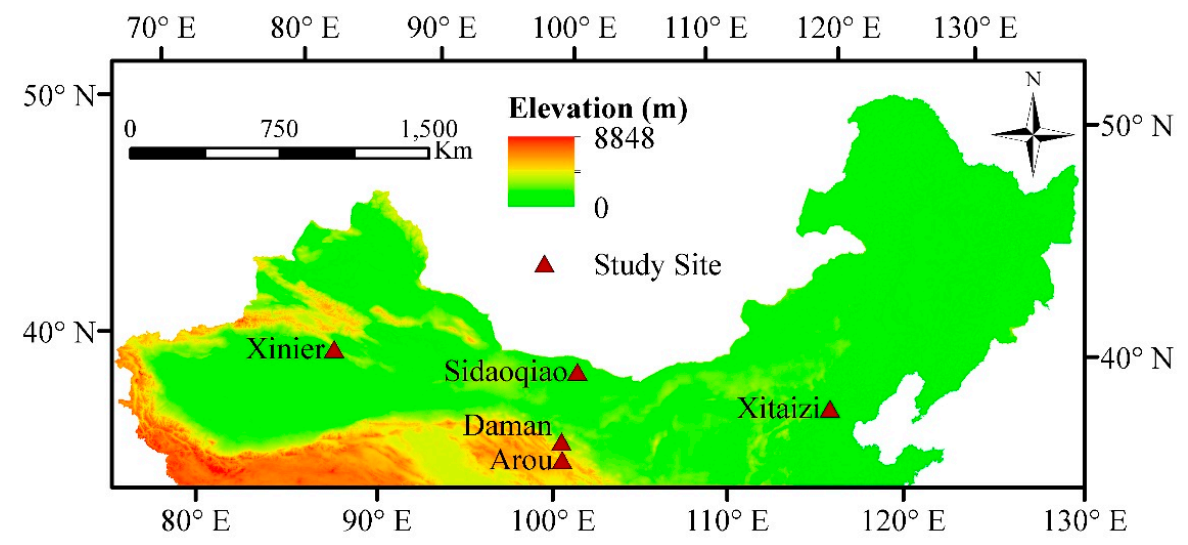

Figure 1. Location of the five sites.

Daman is a typical irrigation district and lies in an artificial oasis of the middle Heihe River watershed. The average annual temperature and precipitation over the past five decades (1961-2010) are around $5.4^{\circ} \mathrm{C}$ and $204.0 \mathrm{~mm}$, respectively, with the annual potential evaporation of $2365.0 \mathrm{~mm}$ [45]. Spring wheat and maize (C4 plant) are the major crops in this site, of which spring wheat is generally sown in late March and harvested in the middle 10 days of July, while maize is sown in late April and harvested in the middle 10 days of September [46]. The maximum canopy height and the maximum LAI are $2.1 \mathrm{~m}$ and about $5.6 \mathrm{~m}^{2} \mathrm{~m}^{-2}$, respectively. Flood irrigation is conducted several times during the growing season. The soil is characterized by silty clay loam and silt loam for the surface and deeper layer, respectively.

Sidaoqiao is located in the Ejin Banner desert-oasis downstream of Heihe River watershed. This site represents an extremely arid region with scarce precipitation (116.8 $\mathrm{mm}$ per year) and high potential evapotranspiration. The potential evaporation is approximately $3755.0 \mathrm{~mm}$ per year and the average temperature is about $9.6^{\circ} \mathrm{C}$ per year, with a frost-free period of 165 days [46]. Vegetation covers ranging from $15 \%$ to $20 \%$ and consists of desert shrubs comprising Populuseuphratica, Tamarix, and other arid region species. The soil is mainly composed of unconsolidated sand and grains and is highly susceptible to wind erosion [47].

Xinier lies on the alluvial plain of the Kaidu-Kongqi River under the southern foot of Tianshan Mountain and northeast edge of Taklimakan Desert. It is characterized by a typical continental desert climate with average temperature of $12.5^{\circ} \mathrm{C}$ and scarce precipitation of $62.0 \mathrm{~mm}$. Annual mean potential evaporation measured with evaporation pan is $2788.0 \mathrm{~mm}$ [48]. The major crop of the study area is cotton, which is the main economic crop in Xinjiang Province, China. Cotton is planted in April and harvested from September to November 2012 [49]. Mulched drip irrigation is applied in 
this site, including surface drip irrigation and film mulching techniques. The depth of frozen soil is approximately $60 \mathrm{~cm}$ and the texture of the soil is loam, consisting of $30 \%$ sand, $5 \%$ silt, and $65 \%$ loam.

Xitaizi is located in the headwater area of Miyun Reservoir, the drinking water source for Beijing, China. This site has a continental monsoon sub-humid continental climate, with a hot/humid summer and a cold/dry winter [50]. The annual precipitation is about $541.0 \mathrm{~mm}$ and the annual average temperature is $7.5^{\circ} \mathrm{C}$. This site is covered by mixed deciduous forest with aspen (Populusdavidiana) as the major species. The overstory canopy averages a height of $12-13 \mathrm{~m}$ and the understory vegetation has a height of $0-1.5 \mathrm{~m}$. Xitaizi site is mostly surrounded by the mountainous region of North China and the main soil types are brown earth and cinnamon soil with a depth of 0-1.5 m.

\subsection{Flux Data}

Carbon dioxide $\left(\mathrm{CO}_{2}\right)$ and water vapor fluxes for the five sites were measured by an eddy flux system, while meteorological instruments are used for monitoring precipitation, temperature pressure, and wind speed. The measurements of Arou, Daman, and Sidaoqiao were collected from Heihe Watershed Allied Telemetry Experimental Research (HiWATER) [44]. These three sites are equipped with the instruments placed on a height of $3.15 \mathrm{~m}$, including Campbell LI-COR 7500 for $\mathrm{CO}_{2}$ flux, LI-COR Li7500 for latent heat flux and a Campbell CSAT3 for sensible heat flux. The meteorological tower is equipped with instrumentation including Campbell CS105 for pressure, Vaisala HMP45C for air temperature and relative humidity, Campbell TE525 for precipitation, MetOne for wind speed and wind direction, etc. In Xinier and Xitaizi, eddy covariance measurements were taken during our own experiments. The two sites have an eddy covariance system with the same equipment, which consists of a fast-response 3D sonic anemometer (CSAT3A, Campbell Scientific Instruments, Logan, UT, USA) for latent heat flux, a fast-response open-path infrared gas analyzer (EC150, Campbell Scientific Instruments) for $\mathrm{CO}_{2}$ and water $\left(\mathrm{H}_{2} \mathrm{O}\right)$ flux, an air temperature and humidity sensor (HMP155A, Vaisala Inc., Woburn, MA, USA), and a micrologger (CR3000, Campbell Scientific Instruments).

The half-hourly data are processed and quality controlled using the Eddypro software as per the method described in Liu et al. [51]. The half-hourly EC data are processed using the REddyProc software [52,53]. Data during the growing season are selected for ET partitioning and analysis. Growing season is defined using the logarithmic model, which is illustrated in Section 2.4.

\subsection{Satellite Data}

To analyze the influence of vegetation on ET partitioning, Vegetation Index (VI) is applied to represent vegetation dynamics and to identify growing season. The Moderate Resolution Imaging Spectroradiometer (MODIS) NDVI product (MOD 13), which has a spatial resolution of $250 \mathrm{~m}$ and time resolution of sixteen days with the same period of flux data, was downloaded from National Aeronautics and Space Administration (NASA) website (https:/ / modis.gsfc.nasa.gov/data/). This NDVI product is calculated from reflectance near-infrared channel and red channel using the following equation:

$$
\mathrm{NDVI}=\frac{\rho_{\text {nir }}-\rho_{\text {red }}}{\rho_{\text {nir }}+\rho_{\text {red }}}
$$

where $\rho_{\text {nir }}$ and $\rho_{\text {red }}$ are the reflectance of near-infrared channel and red channel, respectively.

The NDVI of each site is the NDVI value of the pixel within which the flux site is located. In order to identify the growing season, 16-day NDVI data is then filtered and interpolated to daily NDVI data.

\subsection{Identification of Growing Season}

Growing season is identified according to a logarithmic model based on the daily NDVI data [54]. The model assumed that Green-Up Date (GUD) is the point when the NDVI time series begin to increase rapidly. GUD is defined as the day when the derivative of NDVI's curvature reaches local maximum value for the first time (Figure 2). Similarly, dormancy day is defined as the day when the curvature reaches its local minimum value. 


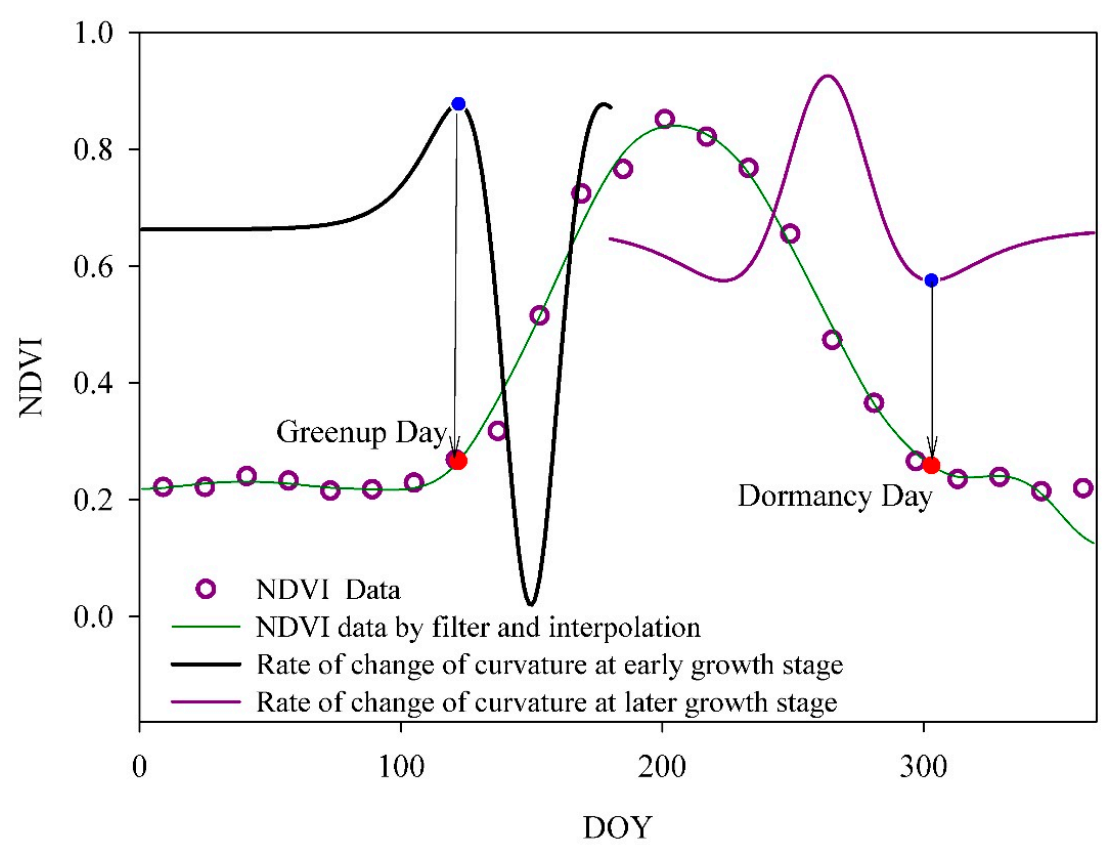

Figure 2. Sketch representing the identification of growing season.

A logistic model with four parameters [54] is applied to fit the NDVI dynamic:

$$
\operatorname{NDVI}(t)=c /\left(1+e^{a+b t}\right)+d
$$

where $t$ is DOY; $\operatorname{NDVI}(t)$ is the NDVI at time $t ; a$ and $b$ are parameters; $c+d$ is the maximum value of NDVI; $d$ is the background value of NDVI, which is the minimum value of NDVI.

Based on the fitted logistic model of NDVI (Equation (2)), the curvature is calculated as follows:

$$
\left.K=-b^{2} c z(1-z)(1+z)^{3} /\left[(1+z)^{4}+\right)(b c z)^{2}\right]^{1.5},
$$

where $z$ is equal to $e^{a+b t}$.

\subsection{ET Partitioning}

ET partitioning is carried out according to the approach based on $u W U E$ [18]. In this method, maximum potential underlying water use efficiency $\left(u W U E_{p}\right)$ is related to transpiration, while the apparent underlying water use efficiency $\left(u W U E_{a}\right)$ is related to evapotranspiration. On an ecosystem scale, the relationship is defined as follows:

$$
\begin{aligned}
& \mu W U E_{p}=\frac{G P P \sqrt{V P D}}{T} \\
& \mu W U E_{a}=\frac{G P P \sqrt{V P D}}{E T},
\end{aligned}
$$

where $u W U E_{p}$ is the potential water use efficiency; $u W U E_{a}$ is the apparent water use efficiency; GPP is the gross primary productivity, which represents carbon assimilation on an ecosystem scale; and VPD is the atmosphere vapor pressure deficit.

The $\mathrm{T} / \mathrm{ET}$ ratio can be determined as follows:

$$
\frac{T}{E T}=\frac{\mu W U E_{a}}{\mu W U E_{p}}
$$


GPP, VPD, and ET can be observed from eddy covariance measurements, whereas $u W U E_{a}$ and $u W U E_{p}$ can be observed through regression analysis.

In this approach, it is assumed that T/ET follows a single-peak diurnal pattern, and the diurnal peak is close to 1 when vegetation coverage is high and soil evaporation can be negligible. Under such circumstances, $u W U E_{p}$ is equal to the maximum value of $u W U E_{a} . u W U E_{p}$ is assumed to be constant for each site for each year. Bremnes [55] and Wang et al. [56] reported that extreme quantiles such as $5 \%$ and $95 \%$ are widely used to describe the lower and upper limits, respectively, for the regression slope. Therefore, in this study, 95th percentile quantile regression is applied to derive the upper slope of GPP VPD ${ }^{0.5}$ over ET and $u W U E_{p}$. For each site, an annual $u W U E_{p}$ for a given year is derived using half-hourly GPP, ET, and VPD data with an intercept of zero. For instance, at the Arou site, we can see from Figure 3 that the slope of the 95th percentile quantile regression (red line) with the annual $u W U E_{p}$ is $12.25 \mathrm{~g} \mathrm{C} \mathrm{hPa}^{0.5} / \mathrm{kg} \mathrm{H}_{2} \mathrm{O}$.
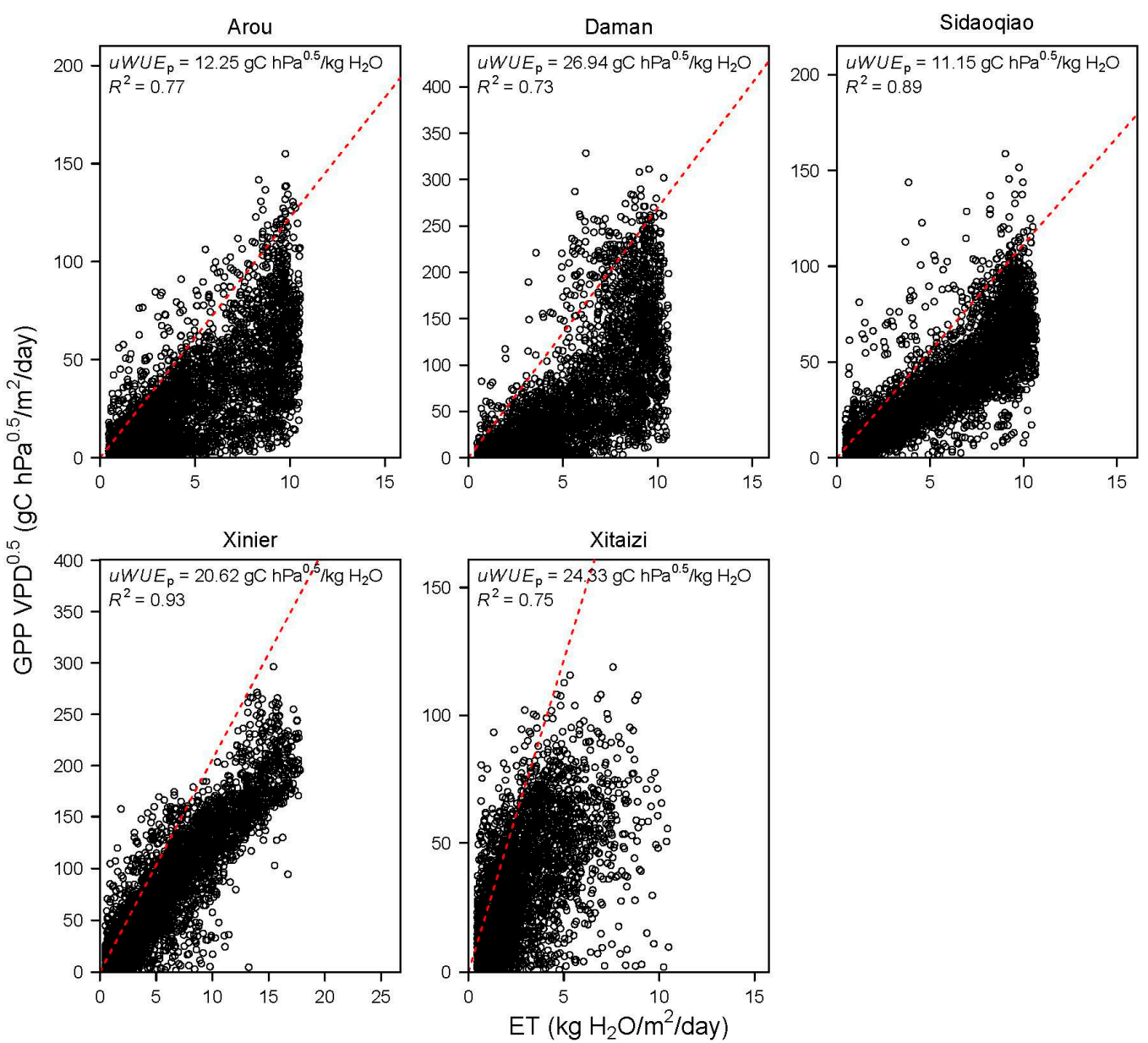

Figure 3. The 95th quantile linear regression using the half-hourly data for each site in 2015.

$u W U E_{a}$ is estimated using linear regression with half-hourly GPP, ET, and VPD measurements for two particular periods of one month and one week. The regression slope of GPP VPD ${ }^{0.5}$ over ET with an intercept of zero represents the $u W U E_{a}$ for each site of given period. As shown in Figure 4 , for the Arou site, the linear regression slope is $7.56 \mathrm{~g} \mathrm{C} \mathrm{hPa}^{0.5} / \mathrm{kg} \mathrm{H}_{2} \mathrm{O}$ in August and $3.73 \mathrm{~g} \mathrm{C} \mathrm{hPa}^{0.5} / \mathrm{kg} \mathrm{H}_{2} \mathrm{O}$ in the 23rd week in 2015. Therefore, the T/ET is $0.62(=7.56 / 12.25)$ for August and $0.30(=3.73 / 12.25)$ for the 23rd week in 2015. The performance of linear regression is evaluated using $R^{2}$ and $p$-value. 
(a) Linear regression using data of August in 2015
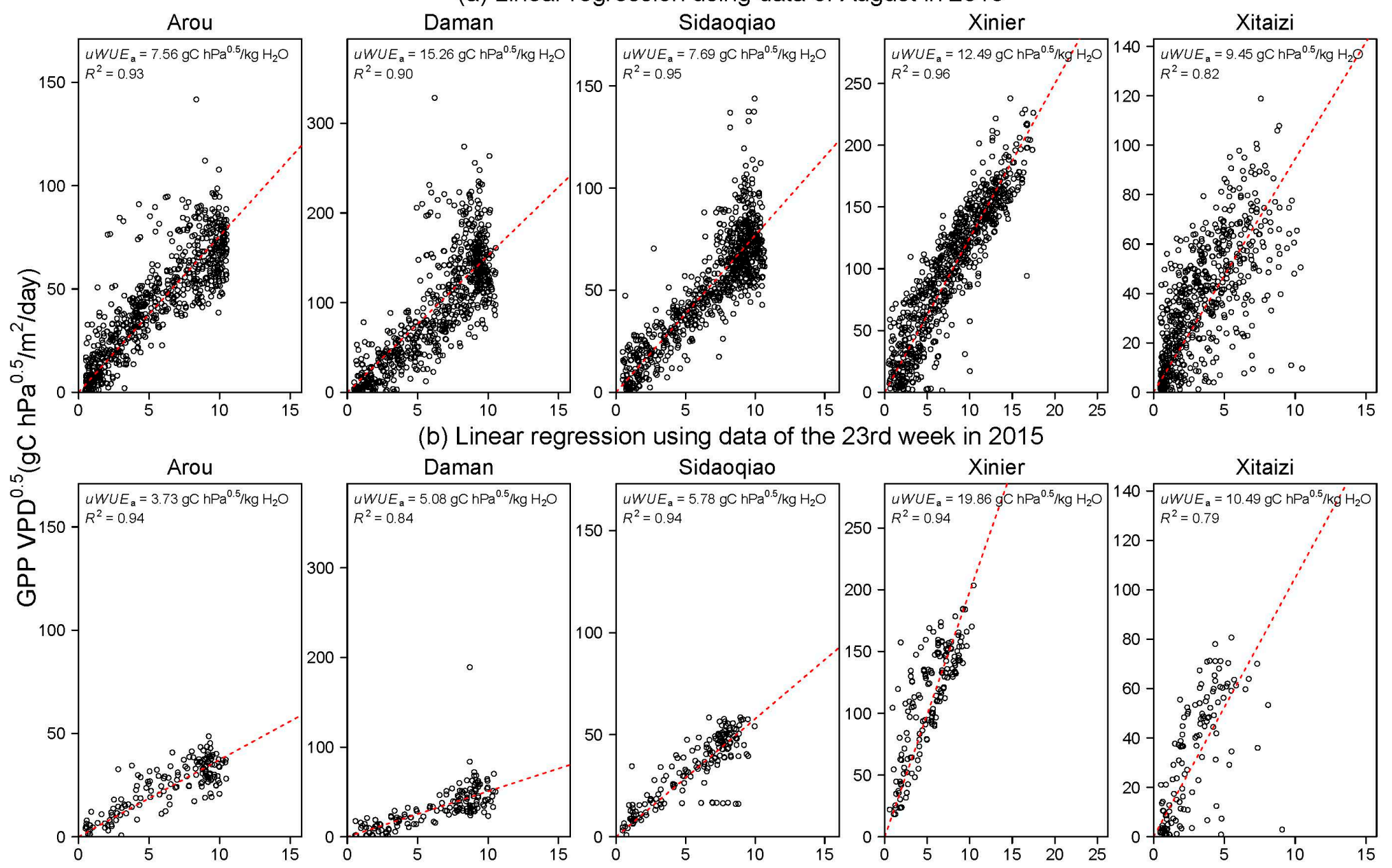

(b) Linear regression using data of the 23rd week in 2015
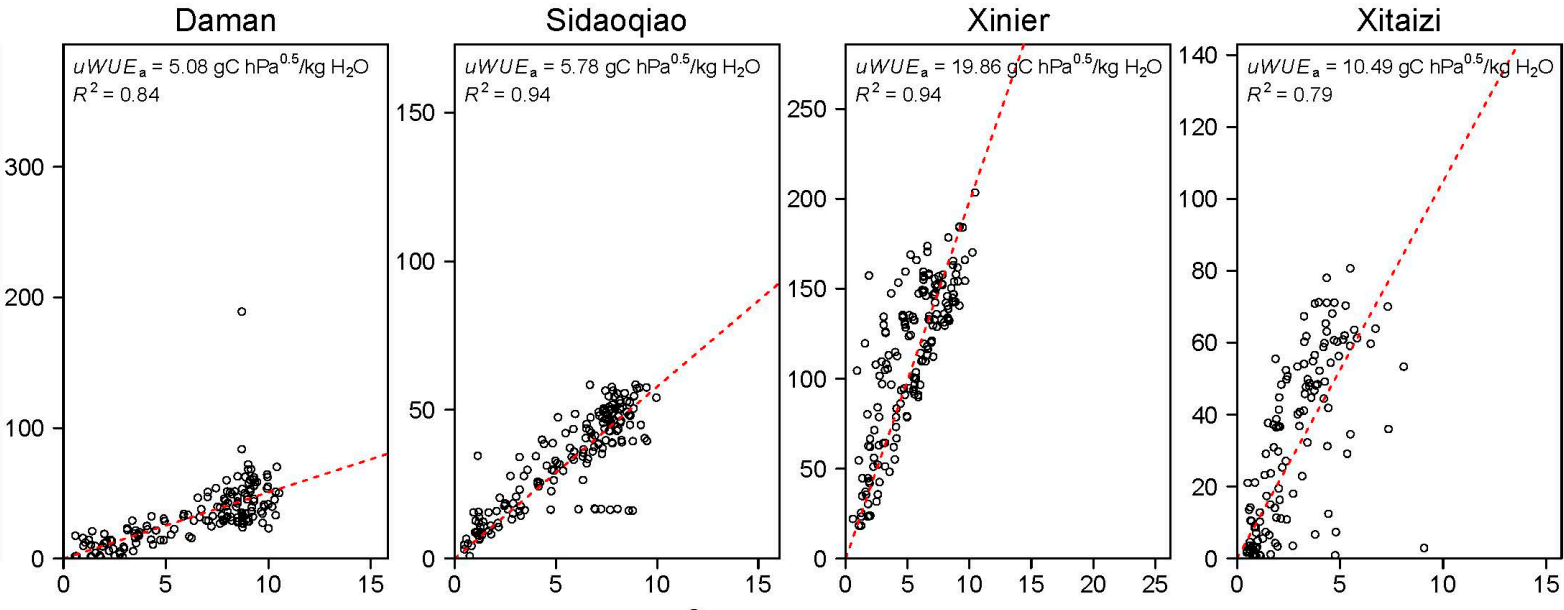

ET $\left(\mathrm{kg} \mathrm{H}_{2} \mathrm{O} / \mathrm{m}^{2} /\right.$ day $)$

Figure 4. Linear regression using the half-hourly data for each site on a monthly and weekly scale. (a) is linear regression using the data of August in 2015, (b) is linear regression using data of the 23rd week in 2015. 


\section{Results and Discussion}

\subsection{Evaluation of Regression Performance}

The reliability of the results estimated from the regression model needs to be evaluated before interpretation of the results. According to the significance test, the $p$-value of the regression for each site is less than 0.001 on a monthly scale whereas almost all of the P value is less than 0.001 on ca weekly scale except for the 39th week at Sidaoqiao and Daman. This indicates that the association between the dependent and the independent variables is statistically significant at the level of 0.001 .

$R^{2}$ is a statistical value to measure how close the dependent and the independent variables are fitted on the regression line. Figure 5 shows the frequency distribution of $R^{2}$ for each site on the monthly and weekly scale. Overall, the value of $R^{2}$ on the weekly scale is higher than that of the monthly scale for each site because the minimum value of $R^{2}$ of each site on the monthly scale is lower than that of the weekly scale and the range of $R^{2}$ for each site is much narrower on the weekly scale. This indicates that there is a strong linear relationship of ET and GPP VPD 0.5 on a weekly scale, and therefore the weekly $u W U E_{a}$ results are utilized for analysis in the present study.

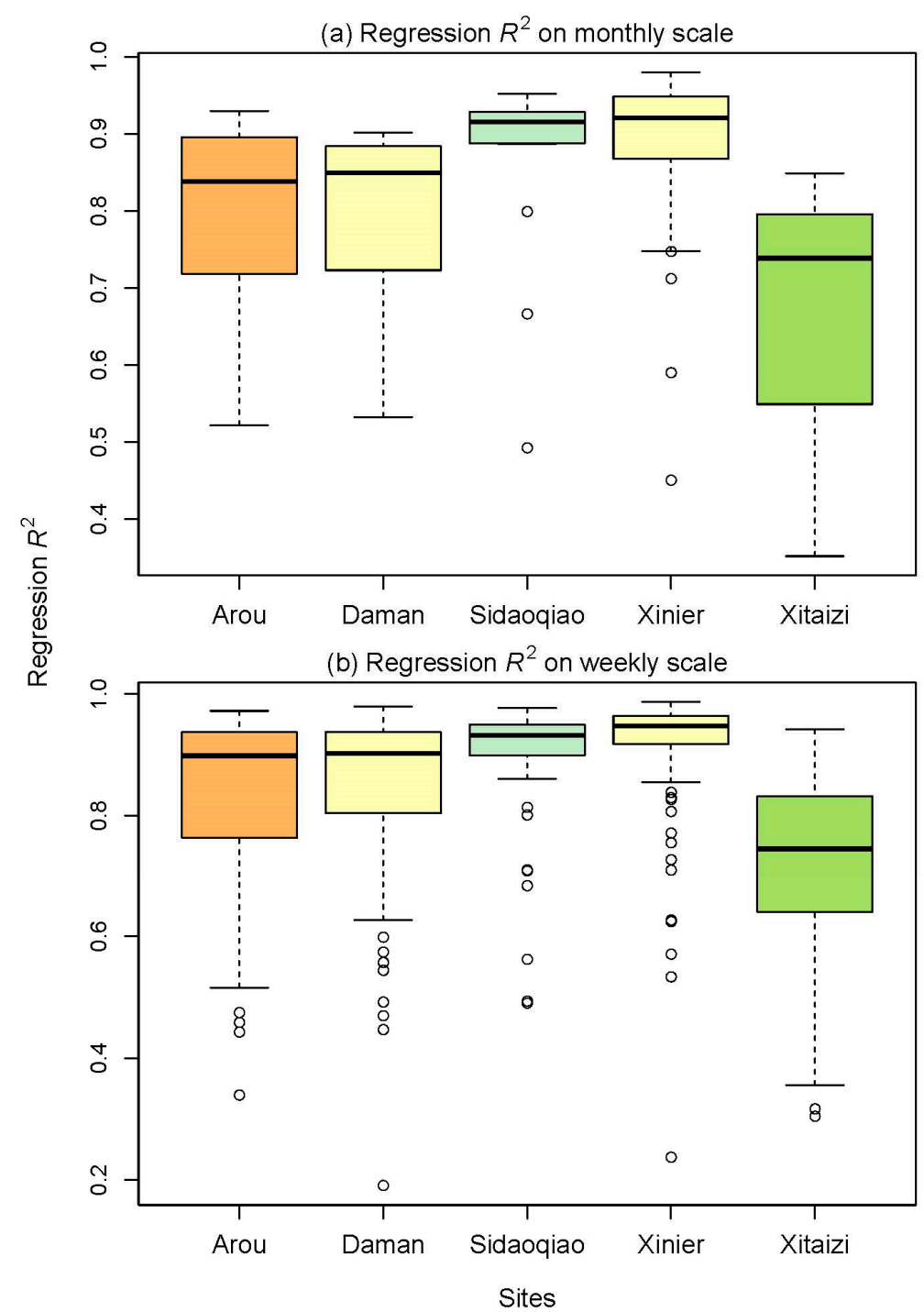

Figure 5. Frequency distribution of $R^{2}$ value. (a) is regression $R^{2}$ using the half-hourly data on monthly scale, (b) is regression $R^{2}$ using the half-hourly data on weekly scale. 


\subsection{Potential and Apparent Underlying Water Use Efficiency}

Table 2 shows the annual $u W U E_{p}$ for the five sites. It is evident from Table 2 that among the three natural vegetation sites, Xitaizi shows the highest average annual $u W U E_{p}$ value of $23.22 \mathrm{~g} \mathrm{C} \mathrm{hPa} a^{0.5} / \mathrm{kg}$ $\mathrm{H}_{2} \mathrm{O}$, followed by Arou and Sidaoqiao with an average annual $u W U E_{p}$ value of $12.34 \mathrm{~g} \mathrm{ChPa}^{0.5} / \mathrm{kg}$ $\mathrm{H}_{2} \mathrm{O}$ and $10.02 \mathrm{~g} \mathrm{C} \mathrm{hPa}^{0.5} / \mathrm{kg} \mathrm{H}_{2} \mathrm{O}$, respectively (Figure 6).

Table 2. A comparison of annual $u W U E_{p}$ for the five sites.

\begin{tabular}{cccccc}
\hline \multirow{2}{*}{ Site } & \multicolumn{5}{c}{$u W U E_{p}\left(\mathrm{~g} \mathrm{C} \mathrm{hPa}^{0.5} / \mathbf{k g ~ H}_{\mathbf{2}} \mathrm{O}\right)$} \\
\cline { 2 - 6 } & $\mathbf{2 0 1 3}$ & $\mathbf{2 0 1 4}$ & $\mathbf{2 0 1 5}$ & $\mathbf{2 0 1 6}$ & Average \\
\hline Arou & 13.27 & 11.51 & 12.25 & - & 12.34 \\
Daman & 25.17 & 26.14 & 26.94 & - & 26.08 \\
Sidaoqiao & 9.23 & 9.66 & 11.15 & - & 10.02 \\
Xinier & 24.00 & 19.23 & 20.61 & 19.87 & 20.61 \\
Xitaizi & - & - & 24.33 & 24.89 & 23.22 \\
\hline
\end{tabular}

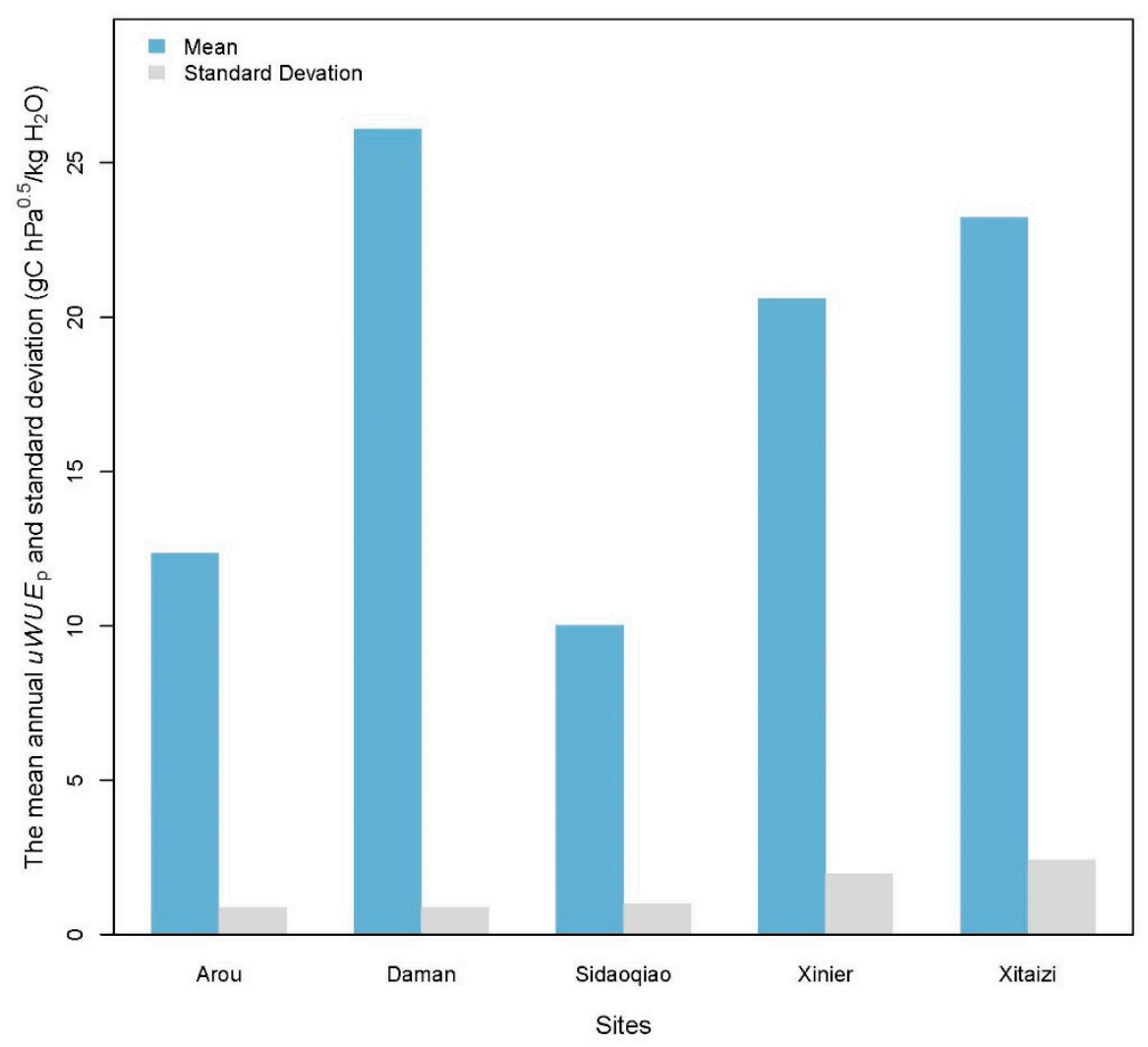

Figure 6. Annual $u W U E_{p}$ for the five sites.

The weekly $u W U E_{a}$ of Xitaizi ranges from 2.44 to $18.67 \mathrm{~g} \mathrm{C} \mathrm{hPa}^{0.5} / \mathrm{kg} \mathrm{H}_{2} \mathrm{O}$, with an average of $9.54 \mathrm{~g} \mathrm{C} \mathrm{hPa}^{0.5} / \mathrm{kg} \mathrm{H}_{2} \mathrm{O}$, the highest among the three vegetation sites when compared with Arou and Sidaoqiao, which range from 1.01 to $21.63 \mathrm{~g} \mathrm{C} \mathrm{hPa}^{0.5} / \mathrm{kg} \mathrm{H}_{2} \mathrm{O}$ with an average of $10.15 \mathrm{~g} \mathrm{C} \mathrm{hPa}^{0.5} / \mathrm{kg}$ $\mathrm{H}_{2} \mathrm{O}$ and 2.07 to $8.65 \mathrm{~g} \mathrm{C} \mathrm{hPa}^{0.5} / \mathrm{kg} \mathrm{H}_{2} \mathrm{O}$ with an average of $5.95 \mathrm{C} \mathrm{hPa}^{0.5} / \mathrm{kg} \mathrm{H}_{2} \mathrm{O}$, respectively (Figure 7). From the results, it is clear that the annual $u W U E_{p}$ and weekly $u W U E_{a}$ are higher for the deciduous broadleaf forest as compared to grass and shrub. Apart from the difference in vegetation types among the three sites, the difference in precipitation also contributes to the variation in annual $u W U E_{p}$ and weekly $u W U E_{a}$ for the three sites. From Table 1, it is seen that the long-term average annual precipitation is highest at Xitaizi $(541.0 \mathrm{~mm})$, followed by Arou $(445.0 \mathrm{~mm})$ and Sidaoqiao $(116.8 \mathrm{~mm})$. 
Annual $u W U E_{p}$ and weekly $u W U E_{a}$ are positively related to precipitation, as higher precipitation is associated with higher net primary productivity (NPP), leading to higher water use efficiency.

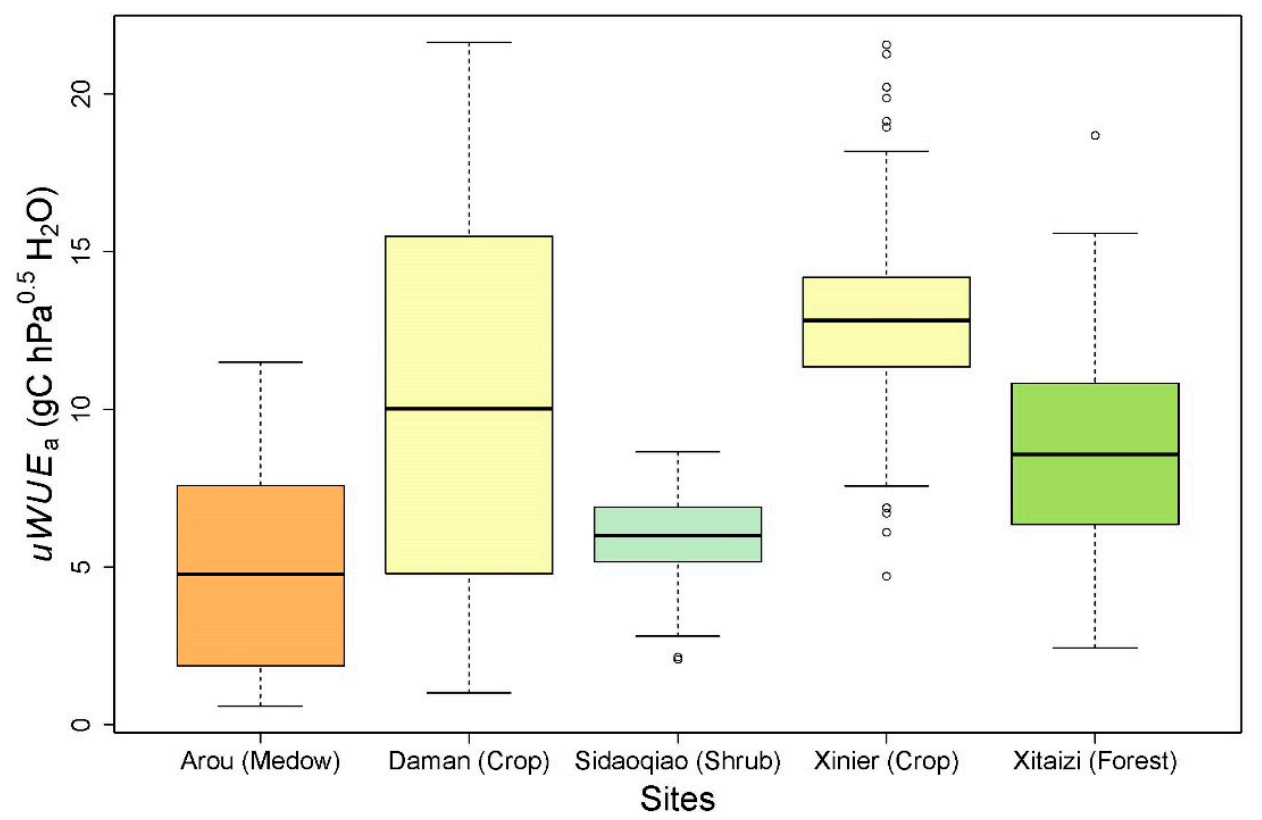

Figure 7. Frequency distribution of weekly $u W U E_{a}$.

The average annual $u W U E_{p}$ for Daman site is $26.08 \mathrm{~g} \mathrm{C} \mathrm{hPa}^{0.5} / \mathrm{kg} \mathrm{H}_{2} \mathrm{O}$, which is much higher than the $20.61 \mathrm{~g} \mathrm{ChPa}^{0.5} / \mathrm{kg}$ of Xinier site. However, the average weekly $u W U E_{a}$ is $10.15 \mathrm{~g} \mathrm{C} \mathrm{hPa}^{0.5} / \mathrm{kg}$ for Daman, which is lower than the $12.82 \mathrm{~g} \mathrm{C} \mathrm{hPa}^{0.5} / \mathrm{kg}$ at Xinier and might be due to the difference in irrigation schemes between the two sites (Figure 7). In Daman, flood irrigation is conducted only four times during the growing season, which causes a dramatic distinction in soil water and ET between irrigated days and non-irrigated days and leads to a high inter-annual variation of $u W U E_{a}$. In contrast, mulch drip irrigation is applied at Xinier during the growing season once a week or less than once a week (during the boll stage), comprising 11 irrigation events in total. Consequently, the variation in soil water and ET at the Xinier site is much smaller compared to the Daman site, which leads to a lower variation in $u W U E_{a}$.

\subsection{ET Partitioning}

Figure 8 shows the variation in T/ET ratio for five different sites. Of the three natural vegetation sites, the average weekly T/ET ratio is highest for Sidaoqiao (0.59) and lowest for Xitaizi (0.36). In contrast, the averaged $u W U E_{a}$ of Sidaoqiao is the lowest, whereas that of Xitaizi is relatively high. It is also observed that the T/ET ratio is negatively related to precipitation for the three sites; for instance, a site with lower annual precipitation has a higher T/ET ratio. It is also evident from Figure 8 that the T/ET ratio of the three sites shows a different level of variation: Arou has a larger variation range from 0.04 to 0.93 compared with the other two sites, whereas Sidaoqiao shows the lowest level of variation in T/ET ratio, ranging from 0.22 to 0.88 . 


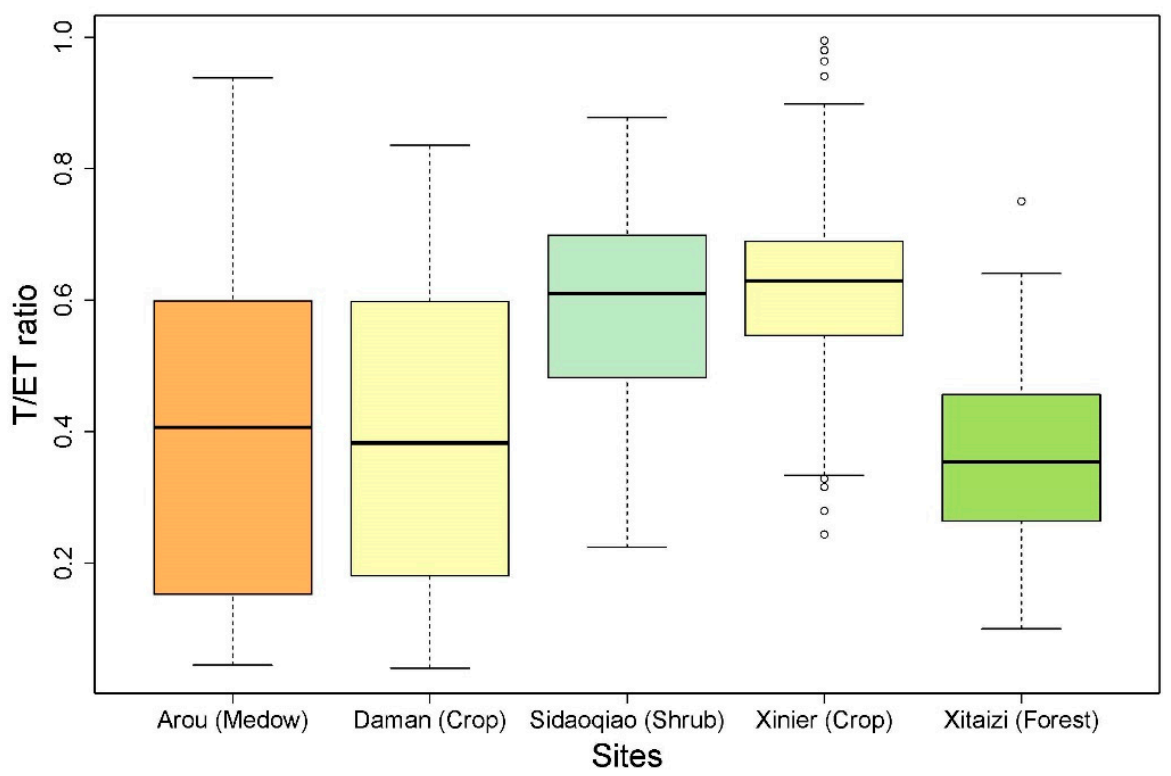

Figure 8. Frequency distribution of weekly T/ET ratio.

Xinier has a higher averaged weekly T/ET ratio (0.63) than the Daman site (0.39), mainly due to the difference in irrigation scheme for the two sites (Figure 8). At the Xinier site, mulch drip irrigation is applied, which delivers water precisely to the root zone of crops and consequently soil water is low in the inter-film zone, resulting in a high fraction of transpiration and low soil evaporation. This result is similar to the finding of Tian et al. [57]. At the Daman site, flood irrigation is conducted and, as a result, there is no obvious difference in soil water under root zone and inter-film zone. Soil evaporation contributes a high portion of ET and consequently the T/ET ratio is lower at Daman.

\subsection{Relationship between T/ET Ratio and Vegetation}

All the sites show different patterns of relationships between T/ET ratio and vegetation index (Figure 9). Arou and Daman represent the synchronous variation of T/ET ratio and NDVI as T/ET ratio grows and decline with increase and decrease of NDVI, respectively. The seasonal dynamic of T/ET ratio and NDVI are both single peak curve and spiked simultaneously. A similar synchronous variation in T/ET ratio and NDVI is shown by Sidaoqiao and Xitaizi at the beginning and end of the growing season when compared with Arou and Daman; however, NDVI remains at a certain level while the T/ET ratio fluctuates in the middle of the growing season. In the case of the Xinier site, the relationship between the T/ET ratio and NDVI is quite different in that the variation of T/ET ratio seems to be irrelevant to NDVI.

In general, four out of five sites show a positive and significant correlation between NDVI and T/ET ratio (Figure 9). Arou and Daman demonstrate an incredibly strong correlation between NDVI and T/ET ratio, with $R^{2}$ values of 0.91 and 0.92 , respectively, which indicates that vegetation has a very strong controlling impact on ET partitioning. Sidaoqiao also shows a positive correlation between T/ET ratio and NDVI with an $R^{2}$ value of 0.56 .

At Arou site, the strong positive correlation between NDVI and T/ET ratio can be well fitted with a quadratic function, indicating a strong controlling impact of NDVI over T/ET ratio. When NDVI is low, the increase in NDVI leads to a slow increase in T/ET ratio; however, when NDVI reaches a certain value (about 0.4 ), the T/ET ratio increases rapidly with the increase of NDVI. Arou site is covered by alpine and mountain meadow and characterized by intermediate precipitation and low temperature. Grass grows slowly at the beginning of the growing season due to the low temperature and consequently there is low vegetation cover; most of the precipitation is allocated to soil evaporation and the T/ET ratio increases slowly at the beginning of growing season. However, grass develops rapidly as temperature increases, resulting in a rapid increase in the $\mathrm{T} / \mathrm{ET}$ ratio. 

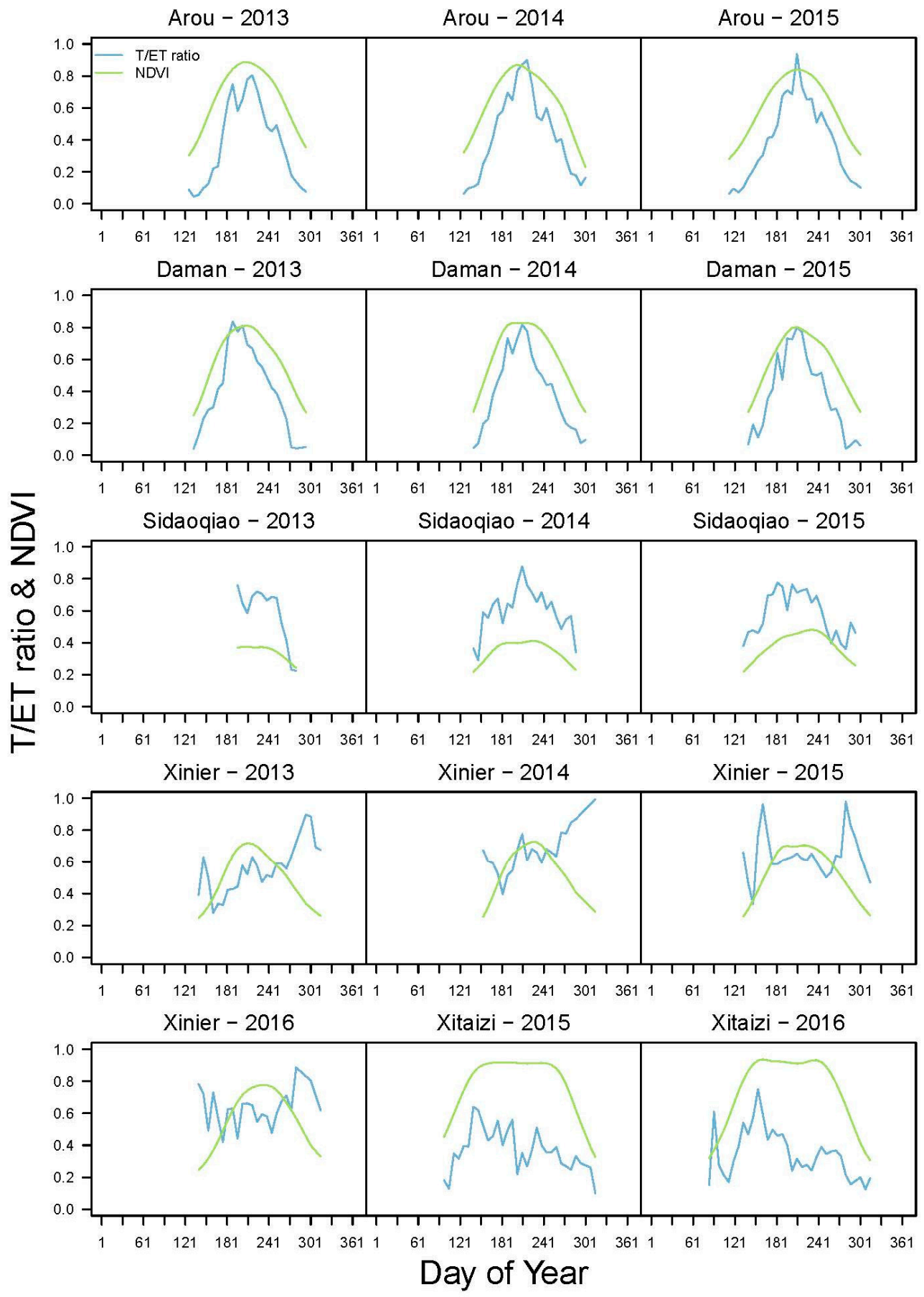

Figure 9. Seasonal dynamic of weekly T/ET ratio.

In the case of Sidaoqiao, the T/ET ratio increases with the increase of NDVI but with a different pattern compared with Arou site. From Figure 10, it is seen that the T/ET ratio increases rapidly and slowly when NDVI is lower and higher than a certain value (around 0.4), respectively. Sidaoqiao is located in an extremely arid region where precipitation is the main factor driving plant growth. Once there is sufficient soil moisture accumulation for plant growth, the sparse desert shrubs on this site recover quickly, leading to a rapid increase in transpiration. However, as the amount of precipitation is low in this site, it cannot afford a high density of vegetation. Consequently, when NDVI reaches a certain value, shrub growth is constrained; thereby transpiration is limited and increases slowly or remains at a certain level. This is also consistent with the study of Scott et al. [9], which stated that in semi-arid areas the increase in woody plants often results in a decrease in vegetation cover, which leads to a decrease in T to ET. 


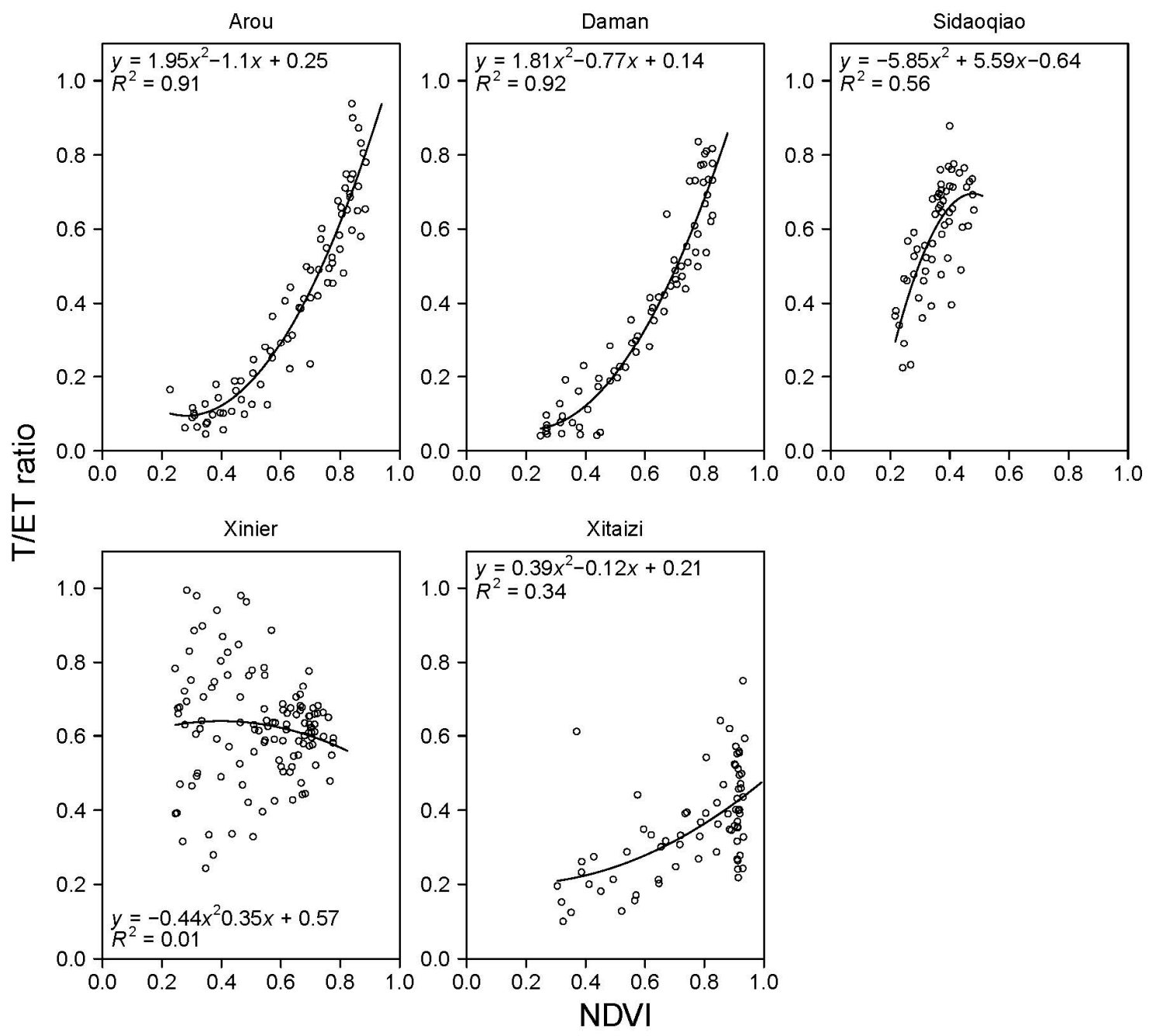

Figure 10. The relationship between NDVI and T/ET ratio.

When NDVI is low, the Xitaizi site shows an increase in T to ET with an increase of NDVI; however, the T/ET ratio becomes insensitive when NDVI is beyond a certain range (Figure 10). This is shown in Figure 10 when the NDVI is about 0.95. The T/ET ratio shows a high level of variation, ranging from 0.2 to 0.8 . This might be the reason for the low NDVI, due to which the potential canopy transpiration determined by environmental factors is much higher than the physiological factors, which also indicates that canopy transpiration is limited by physiological factors under low NDVI conditions. Therefore, the canopy transpiration increases linearly with the increase in NDVI, consequently leading to a rapid increase of T/ET ratio. However, when NDVI is higher than a threshold value, the potential canopy transpiration determined by physiological factors is much higher than the environmental factors. In such a situation, the potential canopy transpiration is constrained by environmental conditions rather than plant physiological factors and thus the T/ET ratio is insensitive to the variation in NDVI. A similar pattern was found by Tie [50] during an assessment of the relationship between LAI and sap flow density (SFD), which concluded that there is a threshold effect associated with the controlling impact of LAI on SFD.

The relationship between T/ET ratio and NDVI is relatively different in the case of the Daman and Xinier sites (Figure 10). The T/ET ratio is highly correlated to NDVI with an $R^{2}$ value of 0.9 at the Daman site, whereas the T/ET ratio is irrelevant to NDVI at the Xinier site due to seasonal variation. This is because both sites are irrigated during the growing season but the type of irrigation and schedule are relatively different. At Daman, flood irrigation is applied about four times during the growing season and soil evaporation contributes a high portion of ET. Transpiration is confined to the amount of 
water that the crop absorbed from the soil, which depends on the density of roots and vegetation cover; therefore, transpiration is mainly determined by physiological factors. In contrast, Xinier is mainly governed by mulched drip irrigation, which is applied in the growing season, from June to August. As drip irrigation transports a very limited amount of water directly to the crop root zone, the soil water in the inter-film zone is very low; as a result, soil evaporation only contributes a small portion to ET when irrigation takes place. Transpiration is highly related to irrigation events, so, even with the same NDVI, transpiration could be quite different with or without irrigation, which leads to an inconsistent relationship between NDVI and T/ET ratio.

\section{Conclusions}

In this study, an ET partitioning approach based on the concept of underlying water use efficiency is used to calculate T/ET ratio and then compare the vegetation's impact on T/ET ratio at five sites in Northern China with different vegetation types. Half-hourly flux eddy covariance data are applied to derive the $u W U E_{p}, u W U E_{a}$, and T/ET ratio. The effect of vegetation on the T/ET ratio is examined using NDVI data by MODIS. The results reveal that the $u W U E_{p}$ and T/ET ratio vary among different sites with different vegetation types and irrigation schemes, and the vegetation effect over ET partitioning shows different type of patterns.

In an alpine meadow site, the T/ET ratio increases gradually when NDVI is low, whereas it increases rapidly as NDVI becomes high.

In arid shrubland, the T/ET ratio grows rapidly when NDVI is low and the T/ET ratio is constrained to a certain value when NDVI reaches a relatively high value.

In deciduous forest, the T/ET ratio becomes insensitive to NDVI variation beyond the threshold value.

For the two crop sites, it is observed that the correlation between T/ET ratio and NDVI is determined by irrigation schemes. The $\mathrm{T} / \mathrm{ET}$ ratio shows a positive correlation with NDVI variation during flood irrigation, whereas it proves irrelevant to NDVI variation during mulch drip irrigation.

In addition, the correlation of T/ET ratio and NDVI becomes more complex when we consider the impact of anthropogenic factors such as irrigation. This study can be extended by taking into account ET partitioning at different sites and under different human activities. This work will help policy makers to better understand the relationship between vegetation and climate change or human activities, and also provide significant information for policy-making on water management.

Author Contributions: Conceptualization, H.H., F.T. and L.C., methodology, H.H., L.C. and H.L.; writing—original draft preparation, H.H. and L.C.; writing-review and editing, all authors.

Funding: This research was funded by the National Science Foundation of China, grant number "51879136", "91647205" and the National Key Research and Development Program of China, grant number "2016YFC0402701", “2017YFD050540503".

Acknowledgments: Lajiao Chen (201704910065) would like to acknowledge the fellowship from the China Scholarship Council (CSC).

Conflicts of Interest: The authors declare no conflict of interest.

\section{References}

1. Fisher, J.B.; Melton, F.; Middleton, E.; Hain, C.; Anderson, M.; Allen, R.; Mccabe, M.F.; Hook, S.; Baldocchi, D.; Townsend, P.A. The future of evapotranspiration: Global requirements for ecosystem functioning, carbon and climate feedbacks, agricultural management, and water resources. Water Resour. Res. 2017, 53, 2618-2626. [CrossRef]

2. Oki, T.; Kanae, S. Global hydrological cycles and world water resources. Science 2006, 313, $1068-1072$. [CrossRef] [PubMed]

3. Lawrence, D.M.; Thornton, P.E.; Oleson, K.W.; Bonan, G.B. The partitioning of evapotranspiration into transpiration, soil evaporation, and canopy evaporation in a GCM: Impacts on land-atmosphere interaction. J. Hydrometeorol. 2007, 8, 862-880. [CrossRef] 
4. Wilcox, B.P.; Turnbull, L.; Young, M.H.; Williams, C.J.; Ravi, S.; Seyfried, M.S.; Bowling, D.R.; Scott, R.L.; Germino, M.J.; Caldwell, T.G.; et al. Invasion of shrublands by exotic grasses: Ecohydrological consequences in cold versus warm deserts. Ecohydrology 2012, 5, 160-173. [CrossRef]

5. Wang, K.; Dickinson, R.E. A review of global terrestrial evapotranspiration: Observation, modeling, climatology, and climatic variability. Rev. Geophys. 2012, 50, RG2005. [CrossRef]

6. Maxwell, R.M.; Condon, L.E. Connections between groundwater flow and transpiration partitioning. Science 2016, 353, 377-380. [CrossRef] [PubMed]

7. Jasechko, S.; Sharp, Z.D.; Gibson, J.J.; Birks, S.J.; Yi, Y.; Fawcett, P.J. Terrestrial water fluxes dominated by transpiration. Nature 2013, 496, 347-350. [CrossRef] [PubMed]

8. Schlesinger, W.H.; Jasechko, S. Transpiration in the global water cycle. Agric. For. Meteorol. 2014, 189, $115-117$. [CrossRef]

9. Scott, R.L.; Huxman, T.E.; Cable, W.L.; Emmerich, W.E. Partitioning of evapotranspiration and its relation to carbon dioxide exchange in a Chihuahuan Desert shrubland. Hydrol. Process. 2006, 20, 3227-3243. [CrossRef]

10. Chen, L.J.; Sun, L.Y.; Liu, W.J.; Wang, L.Z.; Wu, H.; Zhu, A.X.; Luo, Y.Q. Evapotranspiration partitioning using an optimality-based ecohydrological model in a semiarid shrubland. Int. J. Digit. Earth 2018. [CrossRef]

11. Young, M.H.; Caldwell, T.G.; Meadows, D.G.; Fenstermaker, L.F. Variability of soil physical and hydraulic properties at the Mojave Global Change Facility, Nevada: Implications for water budget and evapotranspiration. J. Arid Environ. 2009, 73, 733-744. [CrossRef]

12. Wang, L.; Caylor, K.K.; Villegas, J.C.; Barron-Gafford, G.A.; Breshears, D.D.; Huxman, T.E. Partitioning evapotranspiration across gradients of woody plant cover: Assessment of a stable isotope technique. Geophys. Res. Lett. 2010, 37, L09401. [CrossRef]

13. Wang, L.; Good, S.P.; Caylor, K.K. Global synthesis of vegetation control on evapotranspiration partitioning. Geophys. Res. Lett. 2014, 41, 6753-6757. [CrossRef]

14. Wei, Z.; Yoshimura, K.; Okazaki, A.; Kim, W.; Liu, Z.; Yokoi, M. Partitioning of evapotranspiration using high-frequency water vapor isotopic measurement over a rice paddy field. Water Resour. Res. 2015, 51, 3716-3729. [CrossRef]

15. Raz-Yaseef, N.; Yakir, D.; Schiller, G.; Cohen, S. Dynamics of evapotranspiration partitioning in a semi-arid forest as affected by temporal rainfall patterns. Agric. For. Meteorol. 2012, 157, 77-85. [CrossRef]

16. Moran, M.S.; Scott, R.L.; Keefer, T.O.; Emmerich, W.E.; Hernandez, M.; Nearing, G.S.; O’Neill, P.E. Partitioning evapotranspiration in semiarid grassland and shrubland ecosystems using time series of soil surface temperature. Agric. For. Meteorol. 2009, 149, 59-72. [CrossRef]

17. Raz-Yaseef, N.; Rotenberg, E.; Yakir, D. Effects of spatial variations in soil evaporation caused by tree shading on water flux partitioning in a semi-arid pine forest. Agric. For. Meteorol. 2010, 150, 454-462. [CrossRef]

18. Zhou, S.; Yu, B.; Zhang, Y.; Huang, Y.; Wang, G. Partitioning evapotranspiration based on the concept of underlying water use efficiency. Water Resour. Res. 2016, 52, 1160-1175. [CrossRef]

19. Liu, Y.; Xiao, J.; Ju, W.; Zhou, Y.; Wang, S.; Wu, X. Water use efficiency of China's terrestrial ecosystems and responses to drought. Sci. Rep. 2015, 5, 13799. [CrossRef] [PubMed]

20. Kool, D.; Agam, N.; Lazarovitch, N.; Heitman, J.L.; Sauer, T.J.; Ben-Gal, A. A review of approaches for evapotranspiration partitioning. Agric. For. Meteorol. 2014, 184, 56-70. [CrossRef]

21. Cavanaugh, M.L.; Kurc, S.A.; Scott, R.L. Evapotranspiration partitioning in semiarid shrubland ecosystems: A two-site evaluation of soil moisture control on transpiration. Ecohydrology 2011, 4, 671-681. [CrossRef]

22. Wilson, K.B.; Hanson, P.J.; Mulholland, P.J.; Baldocchi, D.D.; Wullschleger, S.D. A comparison of methods for determining forest evapotranspiration and its components: Sap-flow, soil water budget, eddy covariance and catchment water balance. Agric. For. Meteorol. 2001, 106, 153-168. [CrossRef]

23. Cammalleri, C.; Rallo, G.; Agnese, C.; Ciraolo, G.; Minacapilli, M.; Provenzano, G. Combined use of eddy covariance and sap flow techniques for partition of ET fluxes and water stress assessment in an irrigated olive orchard. Agric. Water Manag. 2013, 120, 89-97. [CrossRef]

24. Scott, R.L.; Biederman, J.A. Partitioning evapotranspiration using long-term carbon dioxide and water vapor fluxes. Geophys. Res. Lett. 2017, 44, 6833-6840. [CrossRef]

25. Zeggaf, A.T.; Takeuchi, S.; Dehghanisanij, H.; Anyoji, H.; Yano, T. A Bowen ratio technique for partitioning energy fluxes between maize transpiration and soil surface evaporation. Agron. J. 2008, 100, 988-996. [CrossRef] 
26. Holland, S.; Heitman, J.L.; Howard, A.; Sauer, T.J.; Giese, W.; Ben-Gal, A.; Agam, N.; Kool, D.; Havlin, J. Micro-Bowen ratio system for measuring evapotranspiration in a vineyard interrow. Agric. For. Meteorol. 2013, 177, 93-100. [CrossRef]

27. Sakuratani, T. A heat balance method for measuring water flux in the stem of intact plants. J. Agric. Meteorol. 1981, 37, 9-17. [CrossRef]

28. Mitchell, P.J.; Veneklaas, E.; Lambers, H.; Burgess, S.S. Partitioning of evapotranspiration in a semi-arid eucalypt woodland in south-western Australia. Agric. For. Meteorol. 2009, 149, 25-37. [CrossRef]

29. Boast, C.W.; Robertson, T.M. A "Micro-Lysimeter" Method for Determining Evaporation from Bare Soil: Description and Laboratory Evaluation 1. Soil Sci. Soc. Am. J. 1982, 46, 689-696. [CrossRef]

30. Shawcroft, R.W.; Gardner, H.R. Direct evaporation from soil under a row crop canopy. Agric. Meteorol. 1983, 28, 229-238. [CrossRef]

31. Wei, Z.; Lee, X.; Wen, X.; Xiao, W. Evapotranspiration partitioning for three agro-ecosystems with contrasting moisture conditions: A comparison of an isotope method and a two-source model calculation. Agric. For. Meteorol. 2018, 252, 296-310. [CrossRef]

32. Stannard, D.I.; Weltz, M.A. Partitioning evapotranspiration in sparsely vegetated rangeland using a portable chamber. Water Resour. Res. 2006, 42. [CrossRef]

33. Rothfuss, Y.; Biron, P.; Braud, I.; Canale, L.; Durand, J.L.; Gaudet, J.P.; Richard, P.; Vauclin, M.; Bariac, T. Partitioning evapotranspiration fluxes into soil evaporation and plant transpiration using water stable isotopes under controlled conditions. Hydrol. Process. 2010, 24, 3177-3194. [CrossRef]

34. Yepez, E.A.; Huxman, T.E.; Ignace, D.D.; English, N.B.; Weltzin, J.F.; Castellanos, A.E.; Williams, D.G. Dynamics of transpiration and evaporation following a moisture pulse in semiarid grassland: A chamber-based isotope method for partitioning flux components. Agric. For. Meteorol. 2005, 132, 359-376. [CrossRef]

35. Wenninger, J.; Beza, D.T.; Uhlenbrook, S. Experimental investigations ofwater fluxes within the soil-vegetation-atmosphere system: Stable isotopemass-balance approach to partition evaporation and transpiration. Phys. Chem. Earth 2010, 35, 565-570. [CrossRef]

36. Good, S.P.; Soderberg, K.; Guan, K.; King, E.G.; Scanlon, T.M.; Caylor, K.K. $\delta_{2} \mathrm{H}$ isotopic flux partitioning of evapotranspiration over a grass field following a water pulse and subsequent dry down. Water Resour. Res. 2014, 50, 1410-1432. [CrossRef]

37. Hu, Z.M.; Wen, X.F.; Sun, X.M.; Li, L.H.; Yu, G.R.; Lee, X.H.; Li, S.G. Partitioningof evapotranspiration through oxygen isotopic measurements of water poolsand fluxes in a temperate grassland. J. Geophys. Res. 2014, 119, 358-371. [CrossRef]

38. Wang, P.; Yamanaka, T.; Li, X.; Wei, Z. Partitioning evapotranspiration in a temperate grassland ecosystem: Numerical modeling with isotopic tracers. Agric. For. Meteorol. 2015, 208, 16-31. [CrossRef]

39. Wei, Z.; Yoshimura, K.; Wang, L.; Miralles, D.G.; Jasechko, S.; Lee, X. Revisiting the contribution of transpiration to global terrestrial evapotranspiration. Geophys. Res. Lett. 2017, 44, 2792-2801. [CrossRef]

40. Scanlon, T.M.; Sahu, P. On the correlation structure of water vapor and carbon dioxide in the atmospheric surface layer: A basis for flux partitioning. Water Resour. Res. 2008, 44. [CrossRef]

41. Scanlon, T.M.; Kustas, W.P. Partitioning evapotranspiration using an eddy covariance-based technique: Improved assessment of soil moisture and land-atmosphere exchange dynamics. Vadose Zone J. 2012, 11, 3. [CrossRef]

42. Skaggs, T.H.; Anderson, R.G.; Alfieri, J.G.; Scanlon, T.M.; Kustas, W.P. Fluxpart: Open source software for partitioning carbon dioxide and water vapor fluxes. Agric. For. Meteorol. 2018, 253, 218-224. [CrossRef]

43. Baldocchi, D.; Falge, E.; Gu, L.; Olson, R.; Hollinger, D.; Running, S.; Anthoni, P.; Bernhofer, C.; Davis, K.; Evans, R.; et al. FLUXNET: A new tool to study the temporal and spatial variability of ecosystem-scale carbon dioxide, water vapor, and energy flux densities. Bull. Am. Meteorol. Soc. 2001, 82, 2415-2434. [CrossRef]

44. Li, X.; Cheng, G.D.; Liu, S.M.; Xiao, Q.; Ma, M.G.; Jin, R.; Che, T.; Liu, Q.H.; Wang, W.Z.; Qi, Y.; et al. Heihe watershed allied telemetry experimental research (HiWATER): Scientific objectives and experimental design. Bull. Am. Meteorol. Soc. 2013, 94, 1145-1160. [CrossRef]

45. Wen, X.; Yang, B.; Sun, X.; Lee, X. Evapotranspiration partitioning through in-situ oxygen isotope measurements in an oasis cropland. Agric. For. Meteorol. 2016, 230, 89-96. [CrossRef]

46. Zhao, W.; Liu, B.; Chang, X.; Yang, Q.; Yang, Y.; Liu, Z.; Cleverly, J.; Eamus, D. Evapotranspiration partitioning, stomatal conductance, and components of the water balance: A special case of a desert ecosystem in China. J. Hydrol. 2016, 538, 374-386. [CrossRef] 
47. Zhao, W.; Liu, B. The response of sap flow in shrubs to rainfall pulses in the desert region of China. Agric. For. Meteorol. 2010, 150, 1297-1306. [CrossRef]

48. Zhang, Z.; Hu, H.C.; Tian, F.; Hu, H.P.; Yao, X.; Zhong, R. Soil salt distribution under mulched drip irrigation in an arid area of northwestern China. J. Arid Environ. 2014, 104, 23-33. [CrossRef]

49. Zhang, Z.; Tian, F.; Hu, H.; Yang, P. A comparison of methods for determining field evapotranspiration: Photosynthesis system, sap flow, and eddy covariance. Hydrol. Earth Syst. Sci. 2014, 10, 14131-14187. [CrossRef]

50. Tie, Q.; Hu, H.; Tian, F.; Guan, H.; Lin, H. Environmental and physiological controls on sap flow in a subhumid mountainous catchment in North China. Agric. For. Meteorol. 2017, 240, 46-57. [CrossRef]

51. Liu, S.M.; Xu, Z.W.; Wang, W.; Jia, Z.Z.; Zhu, M.J.; Bai, J.; Wang, J.M. A comparison of eddy-covariance and large aperture scintillometer measurements with respect to the energy balance closure problem. Hydrol. Earth Syst. Sci. 2011, 15, 1291-1306. [CrossRef]

52. Wutzler, T.; Lucas-Moffat, A.; Migliavacca, M.; Knauer, J.; Sickel, K.; Šigut, L.; Menzer, O.; Reichstein, M. Basic and extensible post-processing of eddy covariance flux data with REddyProc. Biogeosciences 2018, 15, 5015-5030. [CrossRef]

53. Falge, E.; Baldocchi, D.; Olson, R.; Anthoni, P.; Aubinet, M.; Bernhofer, C.; Burba, G.; Ceulemans, R.; Clement, R.; Dolman, H.; et al. Gap filling strategies for defensible annual sums of net ecosystem exchange. Agric. For. Meteorol. 2001, 107, 43-69. [CrossRef]

54. Zhang, X.; Friedl, M.A.; Schaaf, C.B.; Strahler, A.H.; Hodges, J.C.; Gao, F.; Reed, B.C.; Huete, A. Monitoring vegetation phenology using MODIS. Remote Sens. Environ. 2003, 84, 471-475. [CrossRef]

55. Bremnes, J.B. Probabilistic wind power forecasts using local quantile regression. Wind Energy 2004, 7, 47-54. [CrossRef]

56. Wang, P.; Yamanaka, T. Application of a two-source model for partitioning evapotranspiration and assessing its controls in temperate grasslands in central Japan. Ecohydrology 2014, 7, 345-353. [CrossRef]

57. Tian, F.; Yang, P.; Hu, H.; Dai, C. Partitioning of Cotton Field Evapotranspiration under Mulched Drip Irrigation Based on a Dual Crop Coefficient Model. Water 2016, 8, 72. [CrossRef]

(C) 2018 by the authors. Licensee MDPI, Basel, Switzerland. This article is an open access article distributed under the terms and conditions of the Creative Commons Attribution (CC BY) license (http:/ / creativecommons.org/licenses/by/4.0/). 